other factors enter into the picture, and the immediate and long-term survival depends largely on the state of the cardiovascular system.

\section{Carcinoma of the Prostate}

The symptoms of carcinoma of the prostate are the same as those of benign enlargement, with the possible addition of sciatic or lumbar pain due to extension of the growth. If the diagnosis is suspected by the induration of the gland on rectal examination a sample of blood should be sent for a serum acid phosphatase estimation and a plain radiograph of the pelvis should be taken; this is the commonest site for osseous metastases, and the film will exclude prostatic calculi.

Treatment by means of oestrogens is usually effective and seems to give better results than orchidectomy. It has a better and quicker effect if any obstrusting tissue is removed by endoscopic resection, and this also provides tissue for histological confirmation of the diagnosis. Of the oestrogens, stilboestrol is the most effective ; it is given by mouth in doses starting with $1 \mathrm{mg}$. thrice daily and working up to $5 \mathrm{mg}$. thrice daily by the fifth day. This dose is continued for several months and, if the response is good, can be reduced gradually until an adequate maintenance dose is found; it must be continued indefinitely, as cessation of treatment is likely to be followed by a recrudescence of symptoms and the appearance of metastases.

There are some side-effects from stilboestrol; if nausea or vomiting is caused the drug should be changed to hexoestrol or dienoestrol in the same or larger dose, or to ethinyl oestradiol in doses of $1 \mathrm{mg}$. three times a day. Other side-effects are pigmentation of the areolae and enlargement of the breasts, diminution in size of the testes and penis, and loss of erections. These are small prices to pay for the control of a malignant growth, and should not be used as an excuse to stop treatment.

Prognosis.-Many patients live for five to ten years in comfort under oestrogen therapy, and the whole outlook of the disease has been altered by its introduction. Bone metastases may regress, and those in the lungs may disappear. Constant vigilance is needed to see that the dose is continued and to make any alterations which may become necessary.

Stilboestrol will not cure benign enlargement, and its speculative use in all cases of prostatic obstruction is to be deprecated. It may mask a difficult diagnosis of early carcinoma and vitiate the possible help of a raised acid phosphatase: It may, however, be used preoperatively in a case of carcinoma which is to be submitted to radical prostatectomy, but the results of this operation in general are not so good as those of conservative treatment.

A circular from the Ministry of $\mathrm{Heal}^{\text {'h }} \mathrm{h}$ to local authorities states that in wartime two types of ambulance stations should be organized-local and main. The local stations would provide first-line cover, and the main stations would be a strategic reserve for the county or county borough council. Volunteers should be encouraged to help if necessary. In an emergency the additional vehicles required will be obtained and distributed under arrangements made centrally. Arrangements for mutual aid between local authorities should be planned in detail.

\section{A CENTURY OF PHYSICIANS}

BY

\section{Sir HENRY BASḤFORD, M.D., F.R.C.P.}

Between the years 1825 and 1925 , excluding those still alive towards the end of 1950,848 members of the medical profession were elected as Fellows of the Royal College of Physicians. They included many who earned renown in their own day, and not a few whose contributions to the art and science of Medicine have become major or minor landmarks. Such, for example, were William Jenner, the first to proclaim typhus and typhoid fevers as separate entities; William Gull, the first publicly to identify the condition known as myxoedema ; Hughlings Jackson, David Ferrier, Mott, Gowers, and Henry Head, all pilgrim fathers in neurology ; Manson, Bruce, and Leishman, giants in the field of tropical medicine; Clifford Allbutt, commemorated in every pocket clinical thermometer; James Mackenzie, the founder of modern cardiology; John Conolly, who did more than any one man to purge from savagery the treatment of lunatics; Henry Maudsley and W. H. R. Rivers, pioneers in psychiatry and anthropology; and the list is far from complete. There were also such great clinicians as William Broadbent, Andrew Clark, Dyce Duckworth, and Bertrand Dawson, and others, such as Richard Quain and William Osler, who assembled the medical knowledge of their time in books of world-wide circulation.

Honours have been paid to them all. Their portraits may be seen hanging upon the walls of college or hospital libraries and board-rooms. But rather less is known, perhaps, of the group-regarded as a group-to which they belonged. What sort of people were they ? Where did they come from? How were they educated? Apart from their common profession, and-if it be accepted as such - their common distinction as Fellows of the Royal College of Physicians, in what were they alike and how did they differ ? Complete answers are, of course, impossible. But perhaps the first, if it is not the most important, thing that strikes an observer of the group as a whole is the remarkable longevity of its members. In the cases of 21 of them, the necessary data are lacking. But the average age of the remaining 827 was a fraction over 70 . More than a quarter of them, 224, lived to be over 80 , including no fewer than 30 nonagenarians. One of them lived to be over 100 , and it would surely be difficult to find a comparable body of men with such a record.

\section{Their Parentage}

Less information is at hand, especially in the case of the earlier elected Fellows, about their parentage. But, of the 422 whose fathers' occupations are known, the great majority belonged to what are usually described as the professional classes. More than a third of them, 164 , were the sons of doctors, and 74 were the sons of Church of England parsons or nonconformist ministers. Another 35 were the sons of barristers or solicitors, 22 were the sons of officers in the Navy, Army, or Mercantile Marine, 16 were the sons of schoolmasters, and 11 of civil or municipal servants, 5 were the sons of architects or surveyors, 5 were the sons of professional artists or musicians, 4 were the sons of engineers, and 2 each of scientists and authors. In the non-professiona! section, 65 were the sons of business men, bankers, 
mill-owners, shipbuilders, shopkeepers, clerks, and craftsmen. Seven were the sons of farmers, nine of landowners and country squires, and one was the son of a Cabinet Minister.

\section{Schooling}

As regards schooling, most of them seem to have been educated at local grammar schools or day schools of the grammar-school type. But the public schools can claim 248 of them. Rugby heads the list of these, with 21 future Fellows. Eton, Harrow, and Charterhouse follow with 14 apiece. Westminster was responsible for 13, Winchester and Edinburgh High School coming next, each with 11 . Shrewsbury produced 9 ; Epsom, St. Paul's, City of London, King's College School, and University College School each produced 8 ; Mill Hill 7; Tonbridge, Clifton, Merchant Taylors', and Christ's Hospital 6 apiece ; Marlborough, Bedford, and Brighton College 5; and almost every other public school contributed one or two to the total. But it would be hard to discern in this particular group of Fellows-at any rate from the strictly professional point of viewany overwhelming advantage accruing from a publicschool education. None of the great quintet, for instance, of Victorian baronets-Gull, Jenner, Quain, Broadbent, or Andrew Clark-went to a public school in the usual sense of the term, and at least two of them were born in the humblest ranks of contemporary society; nor, among so many others, did such men as Hughlings Jackson and James Mackenzie.

The public schools, on the other hand, can be credited -again merely as a few examples-with Henry Acland, a transformer of medical education at Oxford; George Paget, his counterpart at Cambridge ; Bence Jones, the physiologist ; Lewis Jones, one of the first radiologists ; W. H. R. Rivers; Henry Maudsley; Henry Head ; Archibald Garrod, Osler's successor as Regius Professor at Oxford; Raymond Crawfurd, the regenerator of King's College Hospital and Medical School ; and E. C. Perry, who did much the same both for Guy's and for the R.A.M.C., and who was one of the principal founders of the College of Nursing and the Chartered Society of Masseurs.

\section{The University Stage}

As regards the so-called older universities, 197 of these Fellows went to Cambridge and 90 to Oxford, and here another general characteristic of the group begins to declare itself. To a great extent it conforms with the view that the winning of scholarships and prizes at school is a very uncertain indication of success in later life. But in the university stage of their careers-and this is true at all the universities of which they were students -there is an almost monotonous record, in the case of these 848 Fellows, of first-class honours, gold medals, and other distinctions. It is interesting to note toowith a certain sense, perhaps, of nostalgic melancholyhow many of them supplemented their insular studies with long sojourns at such Continental centres of learning as Berlin, Würzburg, Paris, and Vienna, and how many of them were familiar with languages other than their own.

\section{Personal Characteristics}

Not only from this but from their after-histories, a high degree of scholarship and technical ability can be assumed in them all. But what sort of men were they in themselves? Fuller answers may be found in the books that have since been written about a few of them and in the shorter accounts of others to be found in the Dictionary of National Biography. But as regards the majority, it is upon contemporary obituaries that the inquirer must chiefly rely, and the kindly motto of most obituaries is De mortuis nil nisi bonum. This is particularly true, perhaps, of obituaries written by medical men-as most of these were-since the moulding of a doctor, if it tends to make him a trifle sceptical, also tends to make him tolerant or, at any rate, discreet. Read in large numbers, therefore, and in so far as they deal with personal traits, these obituaries are so alike that they might well, in almost equally large numbers, be interchangeable. The good qualities described, or selected for description, seem to have been shared by nearly all the deceased. Nevertheless, and after making every allowance, even the most debunking of historians would probably agree that the valid impression remains of a reasonably conscientious, reasonably good-tempered body of men, doing their best for their patients and living in amity with the world at large.

\section{Recreations and Hobbies}

Several of them amassed fortunes that few of their successors are likely to equal. None of them would seem to have been actually indigent. Most would appear to have been hospitably inclined, though the obituaries admit to a few recluses. Many of them, in addition to their professional activities, were members of town and county councils, justices of the peace, mayors, and occasionally Members of Parliament, and it was one of these, incidentally, who was responsible for introducing the Bill leading to the construction of the Canadian Pacific Railway. The recreations, too, of those who were wise enough to make time for them were comfortingly diverse. A scrutiny shows that fishing was the most popular, and brothers of the art will applaud the resolution of the celebrated alienist who fished for three years with a dry fly without catching a trout by that method. Music, golf, and gardening follow in close attendance, with one of the golfers still regularly playing at the ripe age of 92 .

The collecting of pictures and works of art occupied the leisure of 24 , and 24 were themselves painters, sculptors, or etchers, some of them attaining to the Royal Academy standard of exhibition. Twenty-three were fond of shooting, and 19 were mountaineers. Fifteen were devoted to the study and collection of antiques. Fourteen were practising organists, pianists, or skilled executants with other musical instruments; and another 14. were ornithologists or natural historians. Others were travellers, botanists, yachtsmen, or collectors of old books, stamps, and coins. Half a dozen of them were hunting-men, and some were photographers, astronomers, meteorologists, anthropologists, and archaeologists. One found an absorbing interest in the repair of watches. Another had an odd but apparently fascinating pursuit in the occupation and refashioning of houses-he dwelt in and altered eight at Oxford or near by-and there was a veteran who indulged his passion for dancing up to the age of 84 , only to be surpassed by the golfer already mentioned and the Fellow who kept up his daily swimming until he was 90 .

It is from a study of their hobbies, indeed, that the ghosts begin to appear of a rather more variegated company than the obituaries at first suggest, and an odd sentence or two here and there reinforce the discovery. It is pleasant to reflect, for instance, upon the Fellow 
whose chief boast it was that he had worked as a builder's apprentice upon the great provincial infirmary of which he was ultimately to become a consulting physician. There is the Fellow-afterwards to be followed by another-who settled in Bournemouth at a time when it contained only 300 persons, and lived to see it, largely through his own efforts, a town of 30,000 inhabitants; and there is the Fellow from the North of England who was bold enough to take a house in Harley Street in spite of the fact that another doctor was already established there. There is the Fellow who wrote a learned treatise upon all the precious stones mentioned in the Bible, and journeyed to the island of Cos in order to identify the plane tree under which Hippocrates used to sit. There is the Fellow who married and retired at the age of 52, bought himself a house in the Lake District, and insisted upon dining every night in a velvet suit, with knee-breeches, black silk stockings, and buckled shoes. Another of them-even the obituaries cannot conceal that he was a somewhat difficult colleague, though he built up an enormous practice, ruled with a rod of iron-spent his Alpine holidays immaculately arrayed in a top-hat and frock-coat. And there was the Fellow, son of a West Country surgeon, all of whose eight brothers became doctors, five of them having previously been Wranglers at Cambridge.

A considerable number of these Fellows were distinguished athletes in their youth, and they include a Rugby international, a rowing blue, and one whose record as a hurdler at Cambridge remained unbroken for many years. It would seem difficult, however, to imagine that a Fellow could simultaneously have been a consultant and a county cricketer. But one of them accomplished this, and another was reported to have been the first recruit in the first regiment of what were then called the Volunteers. That Westminster School still stands where it is results mainly from the persistence of another Fellow. It was a Fellow who bestowed their title on the now disappearing cottage hospitals, and there was a Fellow who became such an authority on church liturgies that he was even consulted by the Vatican. Four of them, on retirement, took Holy Orders, and one was a revered Poet Laureate.

\section{Clinician and Adventurer}

All of them now belong to the past-scientists, eccentrics, royal counsellors-and who could say, looking back, which of them led the fullest life or left humanity most in his debt? But if-turning aside from the discoverers-the criteria may for a moment be accepted of contemporary clinical repute and variety of personal experience, there are certainly two who must come very near to bearing off the palms. Both of them, Hermann Weber and Joseph Fayrer, were men of extraordinary vigour and no doubt lucky-each from his own standpoint-in their physical equipment and the opportunities that came to them.

Although he was practising at a time when Jenner, Gull, Richard Quain, Andrew Clark, and Broadbent were all in the field, Weber (with no particular extraneous advantages; he was never on the staff of a teaching hospital) ultimately numbered amongst his patients as many as five Prime Ministers, Derby, Russell, Salisbury, Rosebery, and Campbell-Bannerman. He was an early advocate of the open-air treatment of pulmonary tuberculosis, and that he was far from being merely a fashionable physician can be deduced from the fact that he was also consulted, in their own illnesses, by Gull himself, James Paget, Spencer Wells, and Lister. In addition to all this, his energy was such that he was able to climb the Jungfrau and Wetterhorn at the age of 73 , and he remained in practice till he was 80 . He then devoted himself to the collection of old coins, and for the next 14 years travelled all over South Europe and the Middle East, finishing up as a leading numismatist, accepted as such by the British Museum.

If Fayrer was not so eminent as a clinician, he was even more, perhaps-in the high, Elizabethan sense of the word-an adventurer. Born a year later than Weber, he was the son of a naval officer, Coleridge and Wordsworth being amongst his boyhood's friends. He went to sea at the age of 16 , visiting the West Indies, South America, Havana, and Bermuda, and it was not until he was 19 that he entered Charing Cross Hospital as a medical student. Having qualified, he joined the Navy, but soon afterwards obtained leave to accompany Lord and Lady Mount Edgcumbe on a long tour of France, Germany, and Italy. He learned the language of each country and was believed to be the first Protestant to obtain the degree of M.D. Rome. He then transferred himself to the East India Company, acted as medical officer to a troop-ship, saw active service with the Burma Field Force, learned Hindustani, and became Residency Surgeon at Lucknow. His house was both a hospital and a fort during its seige in the Indian Mutiny. He was the friend of Outram, attended Lawrence, was loaded with medals, gave most of his prize-money to Epsom College-and all this before he was 35 .

He spent his post-war leave in England, where he became a Fellow of the Royal Society and a Fellow of the Royal College of Surgeons at Edinburgh, and, returning to India, was appointed to the Chair of Surgery at Calcutta and did valuable research work upon snakepoisoning. Ill-health brought him finally back to England, though he visited India again with the Prince of Wales, and he became President of the Medical Board at the India Office and a governor of Guy's Hospital, with a considerable private consulting practice, chiefly amongst Anglo-Indians. He spent most of his autumns in Scotland, shooting and deer-stalking, was made a baronet, and between the ages of 72 and 83 divided his time between London and Falmouth, where he was an ardent yachtsman and deep-sea fisherman.

\section{Conclusion}

But such a selection must needs be arbitrary. There were no doubt consultants with practices as large and as well deserved as Weber's and others who encountered perils, in the course of their duty, with a courage equal to that of Fayrer. Many would have been more than content to feel that they had given their names to some laboratory process or a new clan of micro-organisms, to have initiated some overdue sanitary reform, or to have inspired, as teachers, the young entries flowing through their wards and class-rooms. Examples of all such are to be found in the group under review. Requiescant in pace.

My thanks are due to the President and Harveian Librarian of the Royal College of Physicians, at whose suggestion the work was begun that has made this brief epitome possible, and to their successors under whom it was continued; also to the Library Keeper and $\mathrm{Mr}$. G. H. Brown for their unremitting help during that work. 